\title{
The Extent of Carrying out Self-assessment Practices by Leaders in Private Schools in Amman in Accordance with the Standards of the Arab Organization for Quality Assurance of Education
}

\author{
Faten Saeed Mohammed Sada Prof. Khaled Ali Al-Sarhan
}

\begin{abstract}
The present study aimed to explore the extent of carrying out self-assessment practices by leaders in private schools in Amman in accordance with the standards of the Arab Organization for Quality Assurance of Education. To meet the study's goals, a sixty two item questionnaire was developed. This questionnaire sheds a light on six areas. The reliability and validity of the questionnaire were measured. The questionnaire forms were distributed to 256 principals. Those principals were selected randomly. They were selected from the private schools located in Amman. It was found that the extent of carrying out self-assessment practices by leaders in private schools in Amman is high. It was found that there are statistically significant differences -at the statistical significance level of $(a=0.05)$ - between respondents' attitudes which can be attributed to gender. The latter differences are for the favor of females. It was found that there isn't any statistically significant difference - at the statistical significance level of $(a=0.05)$ - between respondents' attitudes which can be attributed to experience. The researchers recommend providing the principals in private schools with training courses about the way of forming groups for carrying out self-assessment. Such training courses must promote knowledge about the way of carrying out selfassessment in accordance with the standards of the Arab Organization for Quality Assurance of Education.
\end{abstract}

Keywords: school leadership, self-assessment, quality standards for education

DOI: $10.7176 / \mathrm{JEP} / 11-9-03$

Publication date:March $31^{\text {st }} 2020$

\section{Introduction}

Since the beginning of the $21^{\text {st }}$ century, people have been facing major challenges. They have been experiencing rapid changes and developments. Therefore, people must keep up with the rapid technological development. Hence, much effort has been exerted to improve the educational sector. The latter sector plays a significant role in the fulfillment of people's aspirations. It plays a significant role in enabling people to handle the challenges associated with changes. It plays a significant role in enabling people to meet the new demands and requirements.

In other words, education plays a major role in developing the state. Improving the quality of the provided education shall positively affect the inputs and outputs of the educational system. Hence, many governments provided much attention to the process of making reforms to the educational sector. Making such reforms shall enable countries to meet many development-related goals.

Educational leadership significantly affects the effectiveness of the educational process. Educational leaders are responsible for running educational institutions. They are responsible for running the routine tasks. They are responsible for influencing employees in a manner that promotes creativity and development among them (AlSoud, 2013).

To ensure that a specific educational institution is distinguished, one must ensure that this institution provides distinguished services. One must ensure that the employees of this institution show a high performance. That shall participate in providing education of high quality. It shall participate in providing education that keep up with the latest administrative and educational developments. Keeping up with the latest developments shall enable the educational institution to achieve excellence through all its processes. It shall participate in having a nation that is capable of meeting the $21^{\text {st }}$ century demands. It should be noted that (quality in education) is a dynamic expression which has various dimensions and levels. The meaning of the term (quality in education) varies from one institution to another due to the variation between institutions in terms of vision, goals and conditions (Bareer, 2010).

Abdeen (2004) defines quality as (a set of characteristics or features that represent the accuracy and comprehensiveness of the provided education and its processes, inputs, and outputs. It stands for the extent of meeting the intended goals through the provided education). Al-Najar defines (quality) as (a set of requirements, conditions and standards that aim at meeting the expectations and desires of the beneficiary).

Rapid development occurred to the term quality. In addition, information revolution and political and economic changes were experienced. In the light of those changes, it has become necessary to assess the quality of the provided education in educational institutions. Carrying out such assessment shall improve the outcomes of educational institutions. That shall make the nation capable of meeting the $21^{\text {st }}$ century demands. Carrying out such assessment shall improve the quality of the provided education and develop the educational process. It shall enable policy makers to set effective educational policies. However, assessment must be carried in a systematic 
and well-planned manner.

Having an effective educational system requires having this system assessed in an accurate and effective manner. Hence, assessment plays a significant role in the educational sector. To illustrate more, the outcomes of the assessment process shall affect the decisions to be made. They shall affect the measures of making changes to the educational system. They shall affect the measures of developing the educational system. If the assessment process is not accurate and efficient, its results shall be misleading. Such misleading results shall negatively affect the procedures and decisions to be taken for developing the educational system (Al-E’taiby, 2008).

Shahat (2003) defines self-assessment as a procedure for measuring the performance efficiency of leaders in a specific educational institution. This procedure is carried out by the leaders themselves. The results of the selfassessment shall enable those leaders to identify the strengths and weaknesses (Shahat, 2003).

Al-Zyadat and Majeed (2007) suggest that self-assessment is a process carried by the school in order to assess its own performance. This process is carried out in the aim of improving the school performance and provide answers to questions related to the school performance in various areas (Al-Zyadat and Majeed, 2007).

The main goal sought from carrying out the self-assessment process is represented in assessing the employees' performance efficiency in carrying out their work tasks. The self-assessment process also aims at improving the future performance of the employees through guiding them. Through carrying out the self-assessment process, an official report shall be provided. This report includes information about the quality, effectiveness and significance of an educational program, project or institution. The main result of this report is based on standards (Al-E'taiby, 2008).

Self-assessment is carried out through collecting data in accordance with specific quality standards. It is carried out in the aim of identify the strengths and weaknesses. It is carried out in the aim of improving performance. It is carried out in the aim of assuring and improving quality (Al-Dajni, 2011).

Self-assessment plays a significant role in improving the overall performance. That is done through measuring the employee's performance and the instutitonal performance. It participates in promoting collabroation among employees in the aim of improving performance. It is considered a requirement that must be met by schools in order for them to develop. Without carrying self-assessment, the school leaders, and owners will not be capable to identify the strengths and weaknesses existing in the school. Without having knowledge about the strengths and weaknesses, the procedures of developing the school shall not be effective. Without having such knowledge, the outcomes of the school shall not improve and the quality of the provided education shall not improve. Without having such knowledge, the elements of the educational system shall not improve. Such elements include: students, teachers, teaching methods and educational programs. However, in order to carry out the self-assessment process effectively, the process must be carried out in accordance with specific assessment standards. These standards must be clear and measurable.

Carrying out the self-assessment process effectively requires having efficient and wise leadership. All the experts who are specialized in educational administration and leadership suggest that school leadership plays a significant role in raising the school performance and the efficiency of the school processes. The rapid developments that occurred to the school leadership science and concepts played a significant role in raising the performance of schools (Al-Soud, 2013).

The leader who has a visionary leadership is capable of utilizing all the available human and physical resources in order to achieve the intended goals. There are initiating and influential leaders who realize the significance of carrying out self-assessment in accordance with quality standards. Those leaders play a significant role in achieving much organizational development. Carrying such assessment shall enable educational institutions to provide distinguished outcomes.

School leadership is practiced through a systematic administrative process inside the school. It involves several interrelated events. It involves planning, coordination, and guidance processes. These processes are carried out in accordance with the public policies and goals of the society and the government (Ayash, 2015).

Al-Fadel (2010) suggests that carrying out self-assessment in schools shall improve the quality of the provided education. Self-assessment shall develop the school staff professionally. It shall assure quality. Assessing the performance of the school administration plays a significant role in improving the educational process. It shall enable the school administration to achieve the intended goals effectively. It shall enable the school administration to adjust itself with the surrounding changes and handle challenges.

In the light of the aforementioned information, it can be concluded that self-assessment and planning play a significant role in achieving development and advancement. Self-assessment shall enable institutions to develop and change. It must be carried out in accordance with professional and quality standards. It must be carried out in an objective and transparent manner. In the light of the aforementioned information, it should be noted that practicing self-assessment by school leaders is significant and beneficial. Hence, the present study aimed to explore the extent of carrying out self-assessment practices by leaders in private schools in Amman in accordance with the standards of the Arab Organization for Quality Assurance of Education. 


\section{Statement of the Problem and the Study's Questions:}

Global attention has been provided to the quality of education and the educational practices. It has been provided in order to improve the outcomes of educational institutions. In order to improve the quality of education, much attention has been provided to self-assessment. Due to the nature of the jobs of the researchers of the present study, they were capable to identify the significance of carrying out self-assessment. One of the researchers of the present study works as an education quality director in a private school in Amman. The other researcher works as a faculty member in the University of Jordan. The latter researcher served as a supervisor for many studies who conducted MA theses in the field of educational administration in the latter university. Through observation and conducting interviews with educational leaders, the researchers noticed that the self-assessment processes are carried out without showing compliance with the standards of the Arab Organization for Quality Assurance of Education. In addition, the researchers noticed that the results of the self-assessment process aren't utilized for making reforms. Hence, they chose the subject of this study in the aim of improving the educational process and its outcomes. For instance, self-assessment provides objective information which enables school leaders to identify weaknesses and strengths. Such information enables school leaders to make plans and reforms effectively. As far as the researchers know, there isn't any study that sheds a light on self-assessment and the extent of carrying out self-assessment practices by school leaders in accordance with the standards of the Arab Organization for Quality Assurance of Education. Thus, the present study fills a gap in the relevant literature.

The problem of the present study is represented in the following question: (What is the extent of carrying out self-assessment practices by leaders in private schools in Amman in accordance with the standards of the Arab Organization for Quality Assurance of Education?). To be specific, the present study aimed to answer the following questions:

Q.1 What is the extent of carrying out self-assessment practices by leaders in private schools in Amman in accordance with the standards of the Arab Organization for Quality Assurance of Education from their perspective?

Q.2. Is there any statistically significant difference -at the statistical significance level of $(a=0.05)$ - between respondents' attitudes in this regard which can be attributed to gender or experience?

\section{The Study's Significance:}

The approaches of educational leadership play a significant role in improving the outcomes of the educational process. They enable leaders to identify the skills and expertise that are needed by the academic and administrative staff in order to develop themselves professionally. Professional development must be carried out in accordance with the standards of the Arab Organization for Quality Assurance of Education. That shall improve the quality of education and the outcomes of the educational process. It shall meet the demands of the labor market and develop the nation. Due to the scarcity of the studies that shed a light on self-assessment, the present study fills a gap in the relevant literature. This study provides researchers with a review of literature about the self-assessment practices by school leaders in accordance with the standards of the Arab Organization for Quality Assurance of Education. To be specific, the present study is significant due to the following reasons:

1) The results of this study shall enable decision makers to improve the performance of schools

2) As far as the researchers know, there isn't any study that sheds a light on self-assessment and the extent of carrying out self-assessment practices by school leaders in accordance with the standards of the Arab Organization for Quality Assurance of Education

3) The results of this study shall enable school leaders to develop themselves professionally and develop their self-assessment skills. They shall enable school leaders to identify the strengths and weaknesses in their schools in order to make the necessary reforms.

4) The results of this study shall enable the concerned officials to make administrative and educational plans to improve the leaders working Jordanian schools. They enable the concerned officials to provides school leaders in Jordan with the necessary training about assessment

\section{The Study's Objectives}

\section{The present study aimed to:-}

1)-Identify the extent of carrying out self-assessment practices by leaders in private schools in Amman in accordance with the standards of the Arab Organization for Quality Assurance of Education from their perspective. 2)- Identify whether there is any statistically significant difference -at the statistical significance level of $(a=0.05)$ between respondents' attitudes in this regard which can be attributed to gender or experience.

\section{The Study's Terms:}

The definitions of the study's terms are listed below:

Self-assessment: It's an ongoing and comprehensive process that enables schools to promote a culture that encourages the staff to carry out ongoing improvement and development (Al-Dajni, 2011).

Self-assessment (operational definition): It's a set of processes that aim at assessing the school performance. 
This assessment is carried out by the leaders of the school itself. It's carried out through collecting data and information about the existent reality in accordance with the quality standards for education. The extent of carrying out self-assessment practices is measured through the study's questionnaire.

The standards of the Arab Organization for Quality Assurance of Education (AROQA): The latter organization is an international non-profit organization created in Belgium in July, 2007. It aims at improving the quality of higher education in countries in gender and the Arab World in particular. It developed standards in the fields of school governance \& leadership, vision \& mission, learning \& education, communication, and quality \& improvement (AROQA, 2014)

\section{The Study's Limits:}

The present study was conducted during the academic year (2019/2020). It targets the leaders who work in private schools in Amman.

\section{Theoretical literature:}

Through this part, the researcher reviews the relevant theoretical literature related to (self-assessment)

\section{Self-assessment:}

Assessment plays a significant role in developing plans of reforms. It is a systematic process that involves collecting information in the aim of making a decision and issuing an evaluative judgment. Self-assessment is a set of operational procedures that are carried out by the ones working in an educational institution in the aim of assessing their own institution by themselves. It is carried out in accordance with the quality assurance standards (The Accreditation Body of Higher Education Institutions, 2010).

Carrying out self-assessment is a prerequisite for developing schools. For instance, the School Control Body provides much attention to self-assessment. The School Control Guide shall enable school leaders to carry out self-assessment effectively (The School Control Guide, 2017).

\section{The significance of self-assessment:}

Educational institutions must provide outcomes of high quality. Hence, carrying out self-assessment practices by school leaders shall enable them to improve the educational processes. If the educational institution utilizes the results of a systematic self-assessment to improve its activities, plans \& processes, the institution shall participate in developing the nation and raising up a generation who is capable of meeting the needs of the nation

The Arab Organization for Quality Assurance of Education (AROQA) (2014) suggests that the benefits of the self-assessment include the following ones:

-Self-assessment improves the quality of the provided school education on the local and regional levels.

-Self-assessment creates a distinguished educational environment. It enriches the educational experiences of students.

-Self-assessment improves the academic, behavioral, and professional performance of school leaders and students. -Self-assessment provides the school staff with professional development opportunities. That is done through providing them with training courses, and holding conferences and workshops for them about the quality of education and school environment.

-Self-assessment provides the resources and material needed for improving the quality of education and making more reforms.

\section{The areas of self-assessment:}

The Accreditation Body of Higher Education Institutions (2010) suggests that self- assessment must involve the following: 1)- Conducting an analysis for the school resources, 2)-Conducting an analysis for the achievements carried out by the school in relation to the students, 3)-Identifying the extent of meeting the intended educational goals, 4)- Assessing activities and relationships \& 5)- Assessing the effectiveness of the planning processes carried out the institution

The UAE Ministry of Education suggests that assessment must involve the following: 1)- Assessing the quality of students' achievements, 2)- Assessing the quality of the personal and social development achieved by students, 3)- Assessing the quality of the teaching processes, 4)- Assessing the quality of the educational climate, 5)- Assessing the quality of the care and guidance provided to students \& 6)- Assessing the quality of the school leadership (The School Control Guide, 2017).

The targeted AROQA standards in this study are the standards related to school governance \& leadership, vision \& mission, learning \& education, communication, and quality \& improvement (AROQA, 2014)

\section{Previous Studies:}

The researchers reviewed several Arab and foreign studies. These studies are presented below from the oldest to 
the most recent ones:

Al-Daradkah (2004) aimed to explore the attitudes of educational leaders towards the extent of carrying out total quality management practices in Al-Balqa Applied University. He aimed to explore whether there are significant differences between the respondents' attitudes which can be attributed to job title, major, experience and academic ranks. A descriptive approach was adopted. The population consists from all the educational leaders who work in Al-Balqa Applied University in various cities in Jordan. The sample consists from 96 educational leaders. A questionnaire was used for collecting data. It was found that the extent of carrying out total quality management practices by educational leaders is moderate. It was found that there is a statistically significant difference between the respondents' attitude which can be attributed to (job title). The latter difference is for the favor of the deans.

Al-Dajni (2011) aimed to explore the effectiveness of the self-assessment process in promoting a culture of quality among the staff working in Palestinian universities in Gaza. He aimed to explore the culture-related problems from the perspective of the staff responsible for assessment. A descriptive analytical process. A questionnaire was used for carrying out assessment. The sample consists from 60 individuals. It was found that carrying out self-assessment process -for institutional planning, administration, resources, and services- has a significant impact on promoting the latter culture. The latter researcher recommends holding training courses and workshops about institutional assessment.

Al-Zghool (2012) conducted a study titled (the extent of possessing self-assessment skills by academic administrators in Jordanian universities). She aimed to explore the extent of possessing self-assessment skills by academic administrators in Jordanian universities. She used a questionnaire. The sample consists from 220 heads of aacademic departments. It was found that there are significant differences between the respondents' attitudes which can be attributed to major. The latter differences are for the favor of the ones who are specialized in human sciences. The latter researcher recommends holding workshops about the way of carrying out self-assessment along with emphasizing the scientific aspects.

Ayash (2015) aimed to explore the extent of carrying out self-assessment practices by the principals who work in the schools affiliated with the United Nations Relief and Works Agency for Palestine Refugees in the Near East (UNRWA). He aimed to explore the relationship between self-assessment and strategic planning. He aimed to explore whether there are significant differences between the respondents attitudes which can be attributed to several variables. An analytical descriptive approach was adopted and a questionnaire was used. The sample consists from 252 female and male principals. Several results were reached and several recommendations were set. The latter researcher recommends developing systemic self-assessment and strategic planning mechanisms to be employed by school principals. He recommends providing school principals with training courses about the assessment methods and instruments.

Yan (2016) aimed to explore the self-assessment practices of Hong Kong secondary school students. He selected a sample consisting from 6125 secondary schools students. Those students were selected from 10 schools located in Hong Kong. The latter researcher used a questionnaire to collect data. It was found that the female students show better self-assessment practices then male students.

Abu Shareb (2017) conducted a study titled (A proposed educational guide for activating the role of principals in assessing teachers' performance in Jordanian secondary schools in accordance with global assessment standards). He adopted a descriptive survey-based approach. He adopted a developmental approach too. He used a questionnaire and selected a stratified random sample consisting from 567 female and male principals. It was found that there isn't any significant difference between the principals' extent of carrying out educational practices. The latter researcher recommends using the proposed educational guide for activating the role of principals in assessing teachers' performance in Jordanian secondary schools. He recommends providing principals with training courses about assessment in an ongoing manner. He recommends developing principals professionally.

Hernandez (2002) conducted a study titled (Total Quality Management in Education: Its. Application in Texas Education District). He aimed to identify whether total quality management meets the intended goals or nor. The sample consists from 120 principal and supervisors. Heh adopted a descriptive approach. He used a questionnaire. It was found that the respondents are satisfied with the performance of the directorate of education. It was found that the respondents are satisfied with the way of assessing students' achievements. However, the respondents suggest that the best methods should be used for assessing the effectiveness of the total quality management.

Cornin (2004) aimed to explore the extent of compliance with the principles of total quality management in New York. He aimed to explore the relationship between TQM and strategic planning. He adopted a descriptive approach. The sample consists from 116 administrators. To meet the study's goals, a questionnaire was used. It was found that the educational institutions in New York employ advanced quality systems.

\section{Comments on the previous studies:}

Through reviewing the aforementioned studies, the researchers noticed the following: 
- Similar to the present study, all the previous studies- including the studies conducted by Abu Shareb (2017) and Al-Dajni (2011)- suggest that self-assessment plays a very significant role in developing educational institutions. - The present study is the only study that explores the extent of carrying out self-assessment practices by leaders in private schools in Amman in accordance with the standards of the Arab Organization for Quality Assurance of Education. The other studies shed a light on different variables. For instance, Abu Shareb (2017) shed a light on assessment practices and their effectiveness in assessing teachers' performance. Al-Zghool (2012) shed a light on assessment processes and development of an administrative guide. Similar to the present study, the population of the study conducted by Ayash (2015) is represented in principals. The aforementioned studies differ from the present study in terms of the spatial dimensions. For instance, the present study was conducted in the private schools in Amman, whereas the study of Ayash (2015) was conducted in the schools affiliated with the United Nations Relief and Works Agency for Palestine Refugees in the Near East (UNRWA).

\section{The Study's methodology:}

The study provides the survey methodology to achieve a goal by building a study tool that revealed the degree of private school leaders practicing self-evaluation:

\section{Study and sample community:}

The study population consists of all principals of private schools in the Amman region and they number 650 (Directorate of Special Education 2020/2020). Whereas, the study sample was chosen randomly, and they numbered (256).

Table (1)

Distribution of a sample of private school leaders, according to the variables of the gender study and experience

\begin{tabular}{|c|c|c|}
\hline Variable & Category & No. \\
\hline \multirow{3}{*}{ Gender } & Male & $\mathbf{1 0 6}$ \\
\cline { 2 - 3 } & female & $\mathbf{1 5 0}$ \\
\cline { 2 - 3 } & Total & $\mathbf{2 5 6}$ \\
\hline \multirow{3}{*}{ Years of Experience } & Less than 5 years & $\mathbf{5 9}$ \\
\cline { 2 - 3 } & From 5-10 years & $\mathbf{1 2 0}$ \\
\cline { 2 - 3 } & More than 10 years & $\mathbf{7 7}$ \\
\cline { 2 - 3 } & Total & $\mathbf{2 5 6}$ \\
\hline
\end{tabular}

The study's instrument:

For the purposes of data collection, the researchers developed a questionnaire to measure the degree of private school leadership practice for self-evaluation, which consisted of six areas of governance and school leadership (10 paragraphs, mission vision (6) paragraphs, teaching and learning (19), auxiliary resources (13), communication and communication (8), Quality improvement (6).

The stability of the study instrument:

To ensure the consistency of the study instrument, the consistency was calculated using the method of internal consistency between the tool's paragraphs, using the Cronbach Alpha Formula. The following table shows the stability coefficients for the fields of the study instrument.

Table (2)

Study instrument stability coefficients

\begin{tabular}{|l|l|l||}
\hline No. & fields & Coefficients of stability in the Cronbach method \\
\hline $\mathbf{1}$ & Governance and school leadership & $\mathbf{0 . 8 0 3}$ \\
\hline $\mathbf{2}$ & Vision and mission & $\mathbf{0 . 7 5 6}$ \\
\hline $\mathbf{3}$ & Teaching and learning & $\mathbf{0 . 8 4 6}$ \\
\hline $\mathbf{4}$ & Help resources & $\mathbf{0 . 8 8 8}$ \\
\hline $\mathbf{5}$ & Communication & $\mathbf{0 . 8 6 4}$ \\
\hline $\mathbf{6}$ & Quality and improvement & $\mathbf{0 . 7 9 8}$ \\
\hline Total & & $\mathbf{0 . 9 5 3}$ \\
\hline
\end{tabular}

It is noted from the previous table that the value of the stability of the Cronbach Alpha for the overall degree of the instrument amounted to (0.953), while the stability factors for the fields of the study tool ranged between $(0.798-0.888)$, and these values are acceptable for the purposes of the current study.

\section{Validate study instrument:}

The content honesty was used so that the study instrument was presented in its initial form to a group of faculty at the University of Jordan and other universities, as they gave their observations and opinions on the suitability of 
the paragraphs and the degree of their affiliation to each field, as well as the clarity of the paragraphs and amending some of them to remain the number of paragraphs (62) paragraphs Divided into six areas.

The structural validity of the study instrument was verified by calculating the Pearson correlation coefficient between the score of each field of the study instrument with the overall degree of the instrument, and the following table shows the results of that.

Table (3)

Evaluate the Pearson correlation coefficients for each area of the study instrument with the overall score for the instrument

\begin{tabular}{|l|l|l||}
\hline No. & Fields & Correlation coefficient in total \\
\hline $\mathbf{1}$ & Governance and school leadership & $\mathbf{0 . 8 5 4} * *$ \\
\hline $\mathbf{2}$ & Vision and mission & $\mathbf{0 . 5 9 7 * *}$ \\
\hline $\mathbf{3}$ & Teaching and learning & $\mathbf{0 . 9 3 8 * *}$ \\
\hline $\mathbf{4}$ & Help resources & $\mathbf{0 . 8 8 3} * *$ \\
\hline $\mathbf{5}$ & Communication & $\mathbf{0 . 7 4 0 * *}$ \\
\hline $\mathbf{6}$ & Quality and improvement & $\mathbf{0 . 8 0 0 * *}$ \\
\hline
\end{tabular}

** Correlation coefficient $D$ at $(\mathbf{0 . 0 1 )}$ level.

It is noted from the previous table that the coefficients of correlation of the fields of the study instrument with the overall degree of the instrument were positive and statistically indicative of the existence of structural validity of the instrument and its fields.

The Pearson correlation coefficient was also calculated between the degree of the paragraph and the domain to which the paragraph belongs, on the one hand, and the degree of the paragraph with the overall degree of the instrument on the other hand, and the following table shows the results of that.

Table (4)

Evaluate the Pearson correlation coefficients for the study instrument paragraphs with the domain to which the paragraph belongs with the total score of the instrument

\begin{tabular}{|c|c|c|c|c|c|}
\hline 1 & $.674^{* *}$ & $.525^{* *}$ & 32 & $.390^{*}$ & $.476^{* *}$ \\
\hline 2 & $.748^{* *}$ & $.670^{* *}$ & 33 & $.659^{* *}$ & $.487^{* *}$ \\
\hline 3 & $.609^{* *}$ & $.382^{*}$ & 34 & $.635^{* *}$ & $.577^{* *}$ \\
\hline 4 & $.659^{* *}$ & $.581^{* *}$ & 35 & $.502^{* *}$ & $.387^{*}$ \\
\hline 5 & $.501^{* *}$ & $.388^{*}$ & 36 & $.665^{* *}$ & $.640^{* *}$ \\
\hline 6 & $.704^{* *}$ & $.643^{* *}$ & 37 & .335 & .321 \\
\hline 7 & $.746^{* *}$ & $.610^{* *}$ & 38 & $.747^{* *}$ & $.736^{* *}$ \\
\hline 8 & $.652^{* *}$ & $.593^{* *}$ & 39 & $.767^{* *}$ & $.579^{* *}$ \\
\hline 9 & $.544^{* *}$ & $.476^{* *}$ & 40 & $.613^{* *}$ & $.564^{* *}$ \\
\hline 10 & .195 & .332 & 41 & $.657^{* *}$ & $.655^{* *}$ \\
\hline 11 & $.706^{* *}$ & $.458^{*}$ & 42 & $.605^{* *}$ & $.493^{* *}$ \\
\hline 12 & $.860^{* *}$ & $.405^{*}$ & 43 & $.753^{* *}$ & $.594^{* *}$ \\
\hline 13 & $.858^{* *}$ & $.503^{* *}$ & 44 & $.656^{* *}$ & $.562^{* *}$ \\
\hline 14 & $.540^{* *}$ & .125 & 45 & $.684^{* *}$ & $.520^{* *}$ \\
\hline 15 & $.705^{* *}$ & $.444^{*}$ & 46 & $.699^{* *}$ & $.646^{* *}$ \\
\hline 16 & .224 & $.440^{*}$ & 47 & $.782^{* *}$ & $.741^{* *}$ \\
\hline 17 & $.596^{* *}$ & $.574^{* *}$ & 48 & $.636^{* *}$ & $.599^{* *}$ \\
\hline 18 & $.387^{*}$ & $.393^{*}$ & 49 & $.934^{* *}$ & $.553^{* *}$ \\
\hline 19 & $.553^{* *}$ & $.569^{* *}$ & 50 & $.678^{* *}$ & .297 \\
\hline 20 & $.567^{* *}$ & $.588^{* *}$ & 51 & $.629^{* *}$ & $.567^{* *}$ \\
\hline 21 & $.499^{* *}$ & $.446^{*}$ & 52 & $.786^{* *}$ & $.844^{* *}$ \\
\hline 22 & $.722^{* *}$ & $.743^{* *}$ & 53 & $.801^{* *}$ & $.637^{* *}$ \\
\hline 23 & $.451^{*}$ & $.384^{*}$ & 54 & $.667^{* *}$ & $.538^{* *}$ \\
\hline 24 & $.735^{* *}$ & $.728^{* *}$ & 55 & $.630^{* *}$ & $.416^{*}$ \\
\hline 25 & $.619^{* *}$ & $.548^{* *}$ & 56 & $.586^{* *}$ & $.368^{*}$ \\
\hline 26 & $.551^{* *}$ & $.659^{* *}$ & 57 & $.576^{* *}$ & $.748^{* *}$ \\
\hline 27 & $.394^{*}$ & .345 & 58 & $.414^{*}$ & $.518^{* *}$ \\
\hline 28 & $.640^{* *}$ & $.632^{* *}$ & 59 & $.661^{* *}$ & $.717^{* *}$ \\
\hline 29 & $.785^{* *}$ & $.803^{* *}$ & 60 & $.745^{* *}$ & .357 \\
\hline 30 & .023 & -.168 & 61 & $.870^{* *}$ & $.512^{* *}$ \\
\hline 31 & $.741^{* *}$ & $.656^{* *}$ & 62 & $.877^{* *}$ & $.731^{* *}$ \\
\hline
\end{tabular}

\footnotetext{
** Correlation coefficient D at (0.01) level. * Correlation coefficient D at (0.05)
} 
It is noted from the previous table that the coefficients of correlation of the instrument's paragraphs with the total degree and the domain to which the paragraph belongs were mostly positive and statistically indicating the existence of the structural validity of the instrument.

Results

By answering her questions, as follows:

The first question: What is the degree of private school leaders practicing self-evaluation based on the standards of the Arab Organization to ensure the quality of education from their point of view?

To answer this question, arithmetic averages and standard deviations were calculated for the degree of private school leaders' practice of self-evaluation based on the standards of the Arab Organization to ensure the quality of education from their point of view in general and for each field of the study tool. Table (5) shows that.

Table (5)

Arithmetic mean, Standard Deviations, and Ranks for the Degree of Private School Leaders Practice SelfAssessment Based on Arab Organization Standards for Quality Assurance of Education from their Point of View Descending

\begin{tabular}{|c|c|c|c|c|c|}
\hline No & Fields & $\begin{array}{l}\text { Arithmetic } \\
\text { mean }\end{array}$ & $\begin{array}{c}\text { Standard } \\
\text { deviation }\end{array}$ & $\begin{array}{l}\text { Ran } \\
k\end{array}$ & 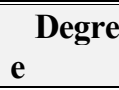 \\
\hline 5 & Communication & 4.47 & 0.36 & 1 & High \\
\hline 2 & Vision and mission & 4.34 & 0.56 & 2 & High \\
\hline 4 & Help resources & 4.32 & 0.38 & 3 & High \\
\hline 1 & $\begin{array}{l}\text { Governance and school } \\
\text { leadership }\end{array}$ & 4.26 & 0.44 & 4 & High \\
\hline 3 & Teaching and learning & 4.18 & 0.39 & 5 & High \\
\hline 6 & Quality and improvement & 4.00 & 0.62 & 6 & High \\
\hline \multicolumn{2}{|c|}{ total } & 4.26 & 0.35 & & \\
\hline
\end{tabular}

It is noted from Table (5) that the degree of leadership of private schools to self-evaluation based on the standards of the Arab Organization to ensure the quality of education from their point of view was high, as the arithmetic mean (4.26) and standard deviation (0.35), and all areas of the tool came in the high degree, as Arithmetic mean ranged between (4.47-4.00), and in the first rank came the field of " communication", with an arithmetic mean (4.47) and a standard deviation (0.36) and a high degree, and in the second rank the field of "vision and message" came with an arithmetic mean (4.34) and a standard deviation (0.56) with a high degree, and the penultimate rank came in the field of teaching and learning "with an average score (4.18) and a standard deviation (0.39) with a high degree, and the field of "quality and improvement" came in the last rank with an average score of 4.00 and a standard deviation (0.62) and with a high degree. She relies on her work on customer service and her ability to communicate to attract students, as well as the interest of schools in education and provide the best for students because of the competition between schools and their abundance in the Amman region, and the interest of school leaders in the quality of education, while the researcher attributes the last rank to the field of quality and improvement as it requires B skills measuring and training in the formation of self-evaluation teams, and agree with that with the study Ayash (2015) and Dujani (2011), and for the paragraphs of each field the results were as follows:

\section{The field of communication}

Arithmetic mean and standard deviations for the degree of private school leaders practicing self-evaluation were calculated based on the standards of the Arab Organization to ensure the quality of education from their point of view of the paragraphs in this field, and Table (6) shows that.

Table (6)

Arithmetic mean, Standard Deviations, and Ranks for the Degree of Private School Leaders Practice SelfAssessment Based on the Arab Organization's Standards for Quality Assurance of Education from their Viewpoint of Paragraphs of Communication Descending

\begin{tabular}{|l|l|l|l|l|l||}
\hline No. & \multicolumn{1}{|c|}{ Statement } & $\begin{array}{c}\text { Arithmetic } \\
\text { mean }\end{array}$ & $\begin{array}{c}\text { Standard } \\
\text { deviation }\end{array}$ & Rank & Degree \\
\hline 8 & $\begin{array}{l}\text { School leadership periodically send notices to parents about } \\
\text { their children's educational level }\end{array}$ & 4.61 & 0.56 & 1 & High \\
\hline 2 & School leadership meets parents through regular meetings & 4.60 & 0.55 & 2 & High \\
\hline 7 & $\begin{array}{l}\text { School leadership uses modern methods to communicate } \\
\text { with parents }\end{array}$ & 4.59 & 0.55 & 3 & High \\
\hline 6 & $\begin{array}{l}\text { School leadership communicates with parents to address } \\
\text { problems related to their children }\end{array}$ & 4.51 & 0.59 & 4 & High \\
\hline 1 & $\begin{array}{l}\text { School leadership forms a council of parents to take their } \\
\text { opinion on many decisions }\end{array}$ & 4.41 & 1.06 & 5 & High \\
\hline
\end{tabular}




\begin{tabular}{|l|l|l|l|l|l||}
\hline No. & \multicolumn{1}{|c|}{ Statement } & $\begin{array}{c}\text { Arithmetic } \\
\text { mean }\end{array}$ & $\begin{array}{c}\text { Standard } \\
\text { deviation }\end{array}$ & Rank & Degree \\
\hline 3 & $\begin{array}{l}\text { School leadership makes effective plans to address student } \\
\text { behavior }\end{array}$ & 4.39 & 0.58 & 6 & High \\
\hline 5 & $\begin{array}{l}\text { School leadership provides an opportunity for parents to } \\
\text { express their opinion on the development of school } \\
\text { performance }\end{array}$ & 4.34 & 0.62 & 7 & High \\
\hline 4 & $\begin{array}{l}\text { School leadership is following teacher treatment plans to } \\
\text { raise underachievement levels }\end{array}$ & 4.33 & 0.67 & 8 & High \\
\hline The total degree for the field of communication & 4.47 & 0.36 & & \\
\hline
\end{tabular}

It is noted from Table (6) that the degree of leadership of private schools to self-evaluation based on the standards of the Arab Organization to ensure the quality of education from their point of view of the paragraphs of the field of communication was high, as the arithmetic mean (4.47) and a standard deviation (0.36), and all the paragraphs in this field came In the high degree, as the arithmetic mean ranged between (4.61-4.33), and the first rank came in paragraph (8) which states "School leadership periodically sends notices to parents about the educational level of their children", with an arithmetic mean (4.61) and a standard deviation (0.56) And with a high degree, came in the second rank Paragraph (2), which T. P. On "School leadership meets parents through periodic meetings," with an average score of (4.60) and standard deviation (0.55) and with a high degree, and it came in the penultimate rank, paragraph (5) which states "School leadership provides an opportunity for parents to express their opinion in developing School performance "with arithmetic mean (4.34) and standard deviation (0.62) and with a high degree, came in the last rank Paragraph (4) which states" School leadership continues treatment plans for teachers to raise the achievement of those with low achievement "with arithmetic mean (4.33) and standard deviation (0.67) And with a high degree. The researchers attribute this to the interest of private schools in communicating and communicating with parents and students by adopting a customer service policy.

1- The field of vision and mission

Arithmetic mean and standard deviations for the degree of private school leaders' practice of self-evaluation were calculated based on the standards of the Arab Organization for Quality Assurance of Education from their point of view of the paragraphs in this field, and Table (7) shows that.

Table (7)

Arithmetic mean, Standard Deviations, and Ranks for the Degree of Private School Leaders Practice SelfAssessment Based on the Standards of the Arab Organization for Quality Assurance of Education from their Point of View

\begin{tabular}{|l|l|l|l|l|l|}
\hline $\mathbf{N}$ & \multicolumn{1}{|c|}{ Statement } & $\begin{array}{l}\text { Arithmetic } \\
\text { mean }\end{array}$ & $\begin{array}{l}\text { Standard } \\
\text { deviation }\end{array}$ & Rank & Degree \\
\hline $\mathbf{1}$ & School leadership formulates an ambitious vision & 4.56 & 0.58 & 1 & High \\
\hline $\mathbf{4}$ & $\begin{array}{l}\text { School leadership formulates its values in line with its } \\
\text { mission }\end{array}$ & 4.53 & 0.59 & 2 & High \\
\hline $\mathbf{5}$ & $\begin{array}{l}\text { School leadership announces the vision and mission of the } \\
\text { school in a clear way }\end{array}$ & 4.47 & 0.75 & 3 & High \\
\hline $\mathbf{6}$ & $\begin{array}{l}\text { School leadership sets learning goals for learning } \\
\text { outcomes in line with its vision }\end{array}$ & 4.32 & 0.79 & 4 & High \\
\hline $\mathbf{2}$ & $\begin{array}{l}\text { School leadership formulates its mission with the } \\
\text { participation of its employees }\end{array}$ & 4.10 & 0.77 & 5 & High \\
\hline $\mathbf{3}$ & $\begin{array}{l}\text { The school develops its vision periodically according to } \\
\text { contemporary developments }\end{array}$ & 4.04 & 0.98 & 6 & High \\
\hline The total score for the field of vision and mission & 4.34 & 0.56 & & \\
\hline
\end{tabular}

It is noted from Table (7) that the degree of leadership of private schools to self-evaluation based on the standards of the Arab Organization to ensure the quality of education from their point of view of the paragraphs of the field of vision and the message was high, as the arithmetic mean (4.34) and a standard deviation (0.56), and all the paragraphs of this field came In the high degree, as the arithmetic mean ranged between (4.56 - 4.04), and paragraph (1) stipulated that "school leadership formulates an ambitious vision" came in the first rank, with an arithmetic mean (4.56) and a standard deviation (0.58) and a high degree, and came in the rank The second paragraph (4) which states, "The school leadership formulates its values in a manner consistent with its mission." With an average of (4.53) and a standard deviation (0.59) with a high degree, and the penultimate rank came in paragraph (2) which states "School leadership formulates its mission with the participation of its employees" with an average of (4.10) and a standard deviation (0.77) and with a high degree, and it came in The last rank, paragraph (3), which states, "The school develops its vision periodically according to contemporary developments," with an average of (4.04) and a standard deviation (0.98) with a high degree. 
The researchers attribute this to the adoption of the leaders of private schools to the approach of continuous development and update its vision, mission and deepening among workers to achieve the school's goals.

\section{Auxiliary resources field}

Arithmetic mean and standard deviations were calculated for the degree of private school leaders' practice of selfevaluation based on the standards of the Arab Organization for Quality Assurance of Education from their point of view of the paragraphs in this field. Table (8) shows that.

Table (8)

Arithmetic mean, Standard Deviations, and Ranks for the Degree of Private School Leaders Practice SelfAssessment Based on Arab Organization Standards for Quality Assurance of Education from their Viewpoint of Paragraphs of Assistive Resources Descending in Descending Order

\begin{tabular}{|c|c|c|c|c|c|}
\hline $\begin{array}{l}\text { No } \\
\text {. }\end{array}$ & Statement & $\begin{array}{l}\text { Arithmetic } \\
\text { mean }\end{array}$ & $\begin{array}{l}\text { Standard } \\
\text { deviations }\end{array}$ & rank & Degree \\
\hline 9 & $\begin{array}{l}\text { School leadership provides libraries equipped with } \\
\text { books }\end{array}$ & 4.56 & 0.65 & 1 & High \\
\hline 11 & $\begin{array}{l}\text { School leadership takes all measures and plans to } \\
\text { provide an element of safety and health }\end{array}$ & 4.56 & 0.56 & 1 & High \\
\hline 7 & $\begin{array}{l}\text { School leadership continues to equip scientific and } \\
\text { professional laboratories with regard to public safety }\end{array}$ & 4.54 & 0.57 & 3 & High \\
\hline 12 & $\begin{array}{l}\text { School leadership provides health, counseling and } \\
\text { mentoring services for students that improve their } \\
\text { learning conditions }\end{array}$ & 4.54 & 0.53 & 3 & High \\
\hline 1 & $\begin{array}{l}\text { School leadership develops a plan of activities in line } \\
\text { with the school's vision }\end{array}$ & 4.53 & 0.63 & 5 & High \\
\hline 8 & $\begin{array}{l}\text { School leadership tracks the school's physical } \\
\text { equipment and infrastructure }\end{array}$ & 4.51 & 0.63 & 6 & High \\
\hline 10 & $\begin{array}{l}\text { School leadership employs modern technology in the } \\
\text { classroom }\end{array}$ & 4.37 & 0.75 & 7 & High \\
\hline 13 & $\begin{array}{l}\text { School leadership provides a comprehensive financial } \\
\text { system that ensures financial strength in a transparent } \\
\text { manner }\end{array}$ & 4.24 & 0.67 & 8 & High \\
\hline 2 & $\begin{array}{l}\text { School leadership implements a club plan and } \\
\text { additional programs that contribute to the development } \\
\text { of the student's personality }\end{array}$ & 4.13 & 0.74 & 9 & High \\
\hline 6 & $\begin{array}{l}\text { School leadership engages in activities that build a } \\
\text { leadership personality for students }\end{array}$ & 4.12 & 0.70 & 10 & High \\
\hline 4 & $\begin{array}{l}\text { School leadership diversifies activities according to } \\
\text { students' development preferences }\end{array}$ & 4.09 & 0.69 & 11 & High \\
\hline 3 & $\begin{array}{l}\text { School leadership assesses the effectiveness of the } \\
\text { activities carried out }\end{array}$ & 4.00 & 0.84 & 12 & High \\
\hline 5 & $\begin{array}{l}\text { School Leaders supports students with an incentive } \\
\text { system for receiving awards from various competitions }\end{array}$ & 3.95 & 0.86 & 13 & High \\
\hline \multicolumn{2}{|c|}{ Overall score for auxiliary resources field } & 4.32 & 0.38 & & \\
\hline
\end{tabular}

It is noted from Table (8) that the degree of leadership of private schools to self-evaluation based on the standards of the Arab Organization to ensure the quality of education from their point of view of the paragraphs of the auxiliary resources was high, as the arithmetic mean (4.32) and a standard deviation (0.38), and all the paragraphs in this field came in the degree The arithmetic mean ranged between (4.56 - 3.95), and first paragraphs (9) stipulated that "school leadership provide library with books", and (11) stipulated that "school leadership take all measures and plans to provide an element of security and health "With an average of (4.56) and two standard deviations (0.65), (0.56) A high degree, and the penultimate rank came in paragraph (3) which states "School leadership assesses the effectiveness of the activities carried out" with an average score of 4.00 and a standard deviation (0.84) and with a high degree, and in the last rank, paragraph (5), which states "supports driving The students are motivated by a system of incentives for obtaining prizes from different competitions "with an arithmetic mean (3.95) and a standard deviation (0.86) and with a high degree. The researchers attribute this to the focus of private schools on resources, activities and the learning environment, and this is one of the reasons that drive parents to place their children in private schools and bear the burden of expenses is their desire to develop their personal skills Their children in distinct environmental and educational conditions.

1- The field of governance and school leadership

Arithmetic mean and standard deviations were calculated for the degree of private school leaders' practice of self- 
evaluation based on the standards of the Arab Organization for Quality Assurance of Education from their point of view of the paragraphs in this field, and Table (9) shows that.

Table 9

Arithmetic mean, Standard Deviations, and Ranks for the Degree of Private School Leaders Practice SelfAssessment Based on the Arab Organization's Standards for Quality Assurance of Education from their Viewpoint of the Paragraphs of Governance and School Leadership Sort Descending

\begin{tabular}{|c|c|c|c|c|c|}
\hline No. & Statement & $\begin{array}{l}\text { Arithmetic } \\
\text { mean }\end{array}$ & $\begin{array}{l}\text { Standard } \\
\text { deviations }\end{array}$ & rank & Degree \\
\hline 1 & $\begin{array}{l}\text { School leadership establishes internal } \\
\text { regulations that are consistent with the } \\
\text { country's education laws }\end{array}$ & 4.77 & 0.47 & 1 & High \\
\hline 9 & $\begin{array}{l}\text { School leadership clarifies internal } \\
\text { regulations and rules for workers since the } \\
\text { beginning of the year }\end{array}$ & 4.62 & 0.53 & 2 & High \\
\hline 8 & $\begin{array}{l}\text { School leadership determines executive } \\
\text { powers within the school according to a clear } \\
\text { organizational structure }\end{array}$ & 4.39 & 0.65 & 3 & High \\
\hline 4 & $\begin{array}{l}\text { School leadership has consistently declined } \\
\text { performance }\end{array}$ & 4.37 & 0.60 & 4 & High \\
\hline 10 & $\begin{array}{l}\text { School leadership establishes clear } \\
\text { mechanisms for evaluating the performance } \\
\text { of educational outcomes }\end{array}$ & 4.32 & 0.72 & 5 & High \\
\hline 2 & $\begin{array}{l}\text { School leadership establishes a strategic plan } \\
\text { according to its vision. }\end{array}$ & 4.31 & 0.77 & 6 & High \\
\hline 5 & $\begin{array}{l}\text { School leadership seeks to provide a positive } \\
\text { school climate for effective education. }\end{array}$ & 4.14 & 0.78 & 7 & High \\
\hline 6 & $\begin{array}{l}\text { School leadership develops its vision in line } \\
\text { with recent developments in learning. }\end{array}$ & 4.03 & 0.85 & 8 & High \\
\hline 3 & $\begin{array}{l}\text { School leadership engages its teachers in } \\
\text { building implementation plans. }\end{array}$ & 4.03 & 0.81 & 8 & High \\
\hline \multirow[t]{2}{*}{7} & $\begin{array}{l}\text { School leadership has a clear performance- } \\
\text { related incentive system }\end{array}$ & 3.62 & 1.16 & 10 & moderate \\
\hline & $\begin{array}{r}\text { College degree is the area of governance and } \\
\text { school leadership }\end{array}$ & 4.26 & 0.44 & & High \\
\hline
\end{tabular}

It is noted from Table (9) that the degree of private school leaders practicing self-evaluation based on the standards of the Arab Organization to ensure the quality of education from their point of view of the paragraphs of the field of governance and school leadership was high, as the arithmetic mean (4.26) and standard deviation $(0.44)$ came, and most of the paragraphs of this The field is in the high degree except for one paragraph that came in the middle class is the paragraph with the number (7), as the arithmetic mean ranged between (4.77 - 3.62), and the first rank came in paragraph (1) which states "School leadership establishes internal systems consistent with the laws of education In the country ", with an arithmetic mean (4.77) and a standard deviation (0.47) A high degree, and the second rank came in paragraph (9), which states, "School leadership clarifies the internal regulations and rules for workers since the beginning of the year," with an average score of (4.62) and standard deviation (0.53) with a high degree, and came to the penultimate rank paragraph (3) that It states, "School leadership participates with its teachers in building implementation plans" with an arithmetic mean (4.03) and a standard deviation (0.81) and with a high degree. Paragraph (7) states that "School leadership applies a clear incentive system related to performance" with an arithmetic mean (3.62) The standard deviation (1.16) is moderate. The researchers attribute the result to the appointment of the orbit leaders Private Q is based on their skills in driving the growth of their enterprises being private profitability. The risk of recruiting the least skilled may lead to serious consequences and failures. Leaders see human capital and teachers as partners in achieving institutional growth and their continued success in attracting students.

\section{1- The field of teaching and learning}

Arithmetic mean and standard deviations were calculated for the degree of private school leaders practicing selfevaluation based on the standards of the Arab Organization to ensure the quality of education from their point of view of the paragraphs in this field, and table (10) shows that. 
Table (10)

Arithmetic mean, Standard Deviations, and Ranks for the Degree of Private School Leaders Practice SelfAssessment Based on the Arab Organization's Standards for Quality Assurance of Education from their Viewpoint of Paragraphs in the Field of Education and Learning Descending

\begin{tabular}{|c|c|c|c|c|c|}
\hline No. & Statement & $\begin{array}{l}\text { Arithmetic } \\
\text { mean }\end{array}$ & $\begin{array}{l}\text { Standard } \\
\text { deviations }\end{array}$ & rank & Degree \\
\hline 1 & $\begin{array}{l}\text { School leadership is constantly developing teacher } \\
\text { teaching practices }\end{array}$ & 4.60 & 0.51 & 1 & High \\
\hline 16 & $\begin{array}{l}\text { School leadership adopts curricula that are appropriate } \\
\text { to students' requirements, in accordance with the laws } \\
\text { of the country }\end{array}$ & 4.47 & 0.57 & 2 & High \\
\hline 8 & $\begin{array}{l}\text { School leadership seeks to develop teachers' skills by } \\
\text { training them in modern learning strategies }\end{array}$ & 4.44 & 0.70 & 3 & High \\
\hline 19 & $\begin{array}{l}\text { School leadership reinforces curricula in line with } \\
\text { modern methods of learning }\end{array}$ & 4.43 & 0.56 & 4 & High \\
\hline 12 & $\begin{array}{l}\text { School leadership takes into account the individual } \\
\text { differences of students in developing plans for the } \\
\text { educational process }\end{array}$ & 4.43 & 0.63 & 4 & High \\
\hline 9 & $\begin{array}{l}\text { School leadership establishes a student monitoring } \\
\text { system in light of the targeted outcomes }\end{array}$ & 4.36 & 0.72 & 6 & High \\
\hline 18 & $\begin{array}{l}\text { School leadership develops educational curricula for } \\
\text { the curriculum in an effective way to achieve targeted } \\
\text { outcomes for students }\end{array}$ & 4.33 & 0.65 & 7 & High \\
\hline 13 & $\begin{array}{l}\text { School leadership employs modern strategies to } \\
\text { achieve educational outcomes }\end{array}$ & 4.32 & 0.63 & 8 & High \\
\hline 2 & $\begin{array}{l}\text { School leadership applies a system to follow the } \\
\text { performance of teachers fairly }\end{array}$ & 4.31 & 0.63 & 9 & High \\
\hline 17 & $\begin{array}{l}\text { School leadership reinforces curricula with } \\
\text { enrichment programs to achieve educational outcomes }\end{array}$ & 4.31 & 0.60 & 9 & High \\
\hline 14 & $\begin{array}{l}\text { School leadership provides electronic systems that } \\
\text { include comprehensive details for students }\end{array}$ & 4.29 & 0.67 & 11 & High \\
\hline 10 & $\begin{array}{l}\text { School leadership plans to engage students in extra- } \\
\text { curricular activities to support their skill. }\end{array}$ & 4.27 & 0.74 & 12 & High \\
\hline 6 & $\begin{array}{l}\text { School leadership establishes a system for assigning } \\
\text { competencies in every objectivity }\end{array}$ & 4.25 & 0.70 & 13 & High \\
\hline 7 & $\begin{array}{l}\text { School leadership directs teachers to use educational } \\
\text { strategies that help students to self-learn }\end{array}$ & 4.14 & 0.77 & 14 & High \\
\hline 15 & $\begin{array}{l}\text { School leadership supports projects to encourage } \\
\text { students to think creatively }\end{array}$ & 4.04 & 0.80 & 15 & High \\
\hline 4 & $\begin{array}{l}\text { School leadership enhances teachers' decision-making } \\
\text { skills by participating in decision-making councils }\end{array}$ & 3.96 & 0.70 & 16 & High \\
\hline 3 & $\begin{array}{l}\text { School leadership applies standards to monitor } \\
\text { outstanding teachers in a transparent manner }\end{array}$ & 3.76 & 0.77 & 17 & High \\
\hline 5 & $\begin{array}{l}\text { School leadership promotes exchange opportunities } \\
\text { between teachers and other similar institutions }\end{array}$ & 3.52 & 1.02 & 18 & Moderate \\
\hline 11 & $\begin{array}{l}\text { School leadership seeks to provide support for people } \\
\text { with special needs to achieve their learning } \\
\text { requirements }\end{array}$ & 3.26 & 1.28 & 19 & moderate \\
\hline \multicolumn{2}{|c|}{ The total degree for the field of teaching and learning } & 4.18 & 0.39 & & High \\
\hline
\end{tabular}

It is noted from Table (11) that the degree of leadership of private schools to self-evaluation based on the standards of the Arab Organization to ensure the quality of education from their point of view of the paragraphs of the field of education and learning was high, as the arithmetic mean (4.18) and a standard deviation (0.39) came, and most of the paragraphs in this field In the high degree except for two paragraphs in the middle class are the paragraphs with numbers $(5,11)$, as the arithmetic mean ranged between $(4.60-3.26)$, and the first rank came in paragraph (1) which states "School leadership works to develop the teaching practices of the teacher Consistently ", with an average of (4.60) and a standard deviation (0.51) with a grade of M. There was a rise in the second rank, paragraph (16), which states, "School leadership adopts appropriate curricula for students' requirements that are in line with the laws of the state", with an average of (4.47) and standard deviation (0.57) and with a high degree, 
and in the penultimate rank, paragraph (5) which It states, "School leadership enhances opportunities for exchanging experiences between teachers and other similar institutions" with an arithmetic mean (3.52) and a standard deviation (1.02) and at a moderate degree. Paragraph (11) states that "School leadership seeks to provide support for people with special needs to achieve Their learning requirements "with mean (3.26) and standard deviation (1.28), and with a mean degree researchers to the importance of the leaders of private schools and their interest in appointing qualified teachers and develop their skills as this is reflected in the educational outcomes that compete with them and is the most prominent reason for the presence of students in a special environment for opportunities of high quality education reflected on their outputs.

\section{Quality and Improvement field}

Arithmetic mean and standard deviations were calculated for the degree of private school leaders practicing selfevaluation based on the standards of the Arab Organization to ensure the quality of education from their point of view of the paragraphs in this field, and table (11) shows that.

\section{Table (11)}

Arithmetic mean, Standard Deviations, and Ranks for the Degree of Private School Leaders Practice SelfAssessment Based on Arab Organization Standards for Quality Assurance of Education from their Viewpoint of Paragraphs of Quality and Improvement Field Descending

\begin{tabular}{|l|l|l|l|l|l||}
\hline No. & \multicolumn{1}{|c|}{ Statement } & $\begin{array}{l}\text { Arithmetic } \\
\text { mean }\end{array}$ & $\begin{array}{l}\text { Standard } \\
\text { deviations }\end{array}$ & rank & Degree \\
\hline 1 & $\begin{array}{l}\text { School leadership compares the percentage of } \\
\text { verification in educational outcomes between years to } \\
\text { measure improvement }\end{array}$ & 4.46 & 0.63 & 1 & High \\
\hline 3 & $\begin{array}{l}\text { School leadership develops improvement plans that } \\
\text { contribute to improving educational outcomes }\end{array}$ & 4.32 & 0.58 & 2 & High \\
\hline 2 & $\begin{array}{l}\text { School Leadership measures customer satisfaction to } \\
\text { benefit from developing improvement plans }\end{array}$ & 4.29 & 0.70 & 3 & High \\
\hline 6 & $\begin{array}{l}\text { School leadership applies education quality standards to } \\
\text { educational processes }\end{array}$ & 3.84 & 0.85 & 4 & High \\
\hline 4 & $\begin{array}{l}\text { School leadership self-assesses according to educational } \\
\text { quality standards }\end{array}$ & 3.71 & 0.98 & 5 & High \\
\hline 5 & $\begin{array}{l}\text { School leadership forms a self-assessment team } \\
\text { according to the quality standards of education }\end{array}$ & 3.41 & 1.24 & 6 & $\begin{array}{l}\text { Moder } \\
\text { ate }\end{array}$ \\
\hline Total score for quality and improvement & 4.00 & 0.62 & High \\
\hline
\end{tabular}

It is noted from Table (11) that the degree of leadership of private schools to self-evaluation based on the standards of the Arab Organization to ensure the quality of education from their point of view of the paragraphs of quality and improvement was high, as the arithmetic mean (4.00) and standard deviation (0.62) came, and most of the paragraphs in this field In the high degree except for one paragraph in the middle class is the paragraph with the number (5), as the arithmetic mean ranged between $(4.46-3.41)$, and the first rank came in paragraph (1) which states "School leadership compares the percentage of verification in educational outcomes between Years to measure the improvement, "with an average of (4.46) and deviation with me Irrigation (0.63) and with a high degree, and in the second rank came paragraph (3) which states "School leadership shall develop developmental improvement plans that contribute to improving educational outcomes", with an average of (4.32) and standard deviation (0.58) and with a high degree, and it came in the penultimate rank Paragraph (4) which states "School leadership assesses itself according to educational quality standards" with an average score of (3.71) and standard deviation (0.98) and with a high degree, and it comes in the last rank Paragraph (5) which states "School leadership forms a team for self-evaluation according to criteria Quality of education "with an average mean (3.41) and a standard deviation (1.24) and an average degree. The researchers attribute, the interest of school leaders in communication, leadership skills and the quality of education and developing a vision and mission all reflect on quality and improvement and help in building development plans that contribute to the quality of education outcomes.

The second question: Are there statistically significant differences in the degree of practicing self-evaluation based on the criteria of the Arab Organization for Quality Assurance of Education for Private School Leaders at the level of significance $(0.05)$ attributable to the variables of the study gender, and experience.

To answer this question, arithmetic mean and standard deviations for the degree of self-evaluation exercise were calculated based on the standards of the Arab Organization for Quality Assurance of Education for Private School Leaders, according to the variables of study, gender, experience, and the following table shows that. 
Table (12)

Arithmetic mean and standard deviations for the degree of practicing self-evaluation based on the standards of the Arab Organization for Quality Assurance of Education for Private School Leaders, according to the variables of study, gender, and experience

\begin{tabular}{||c|c|c|c|c||}
\hline Variable & Category & No. & Arithmetic mean & standard deviation \\
\hline \multirow{3}{*}{ Gender } & Male & 106 & 4.18 & 0.33 \\
\cline { 2 - 5 } & The female & 150 & 4.31 & 0.36 \\
\cline { 2 - 5 } & Total & 256 & 4.26 & 0.35 \\
\hline \multirow{3}{*}{ Years of Experience } & Less than 5 years & 59 & 4.21 & 0.36 \\
\cline { 2 - 5 } & From 5-10 years & 120 & 4.23 & 0.33 \\
\cline { 2 - 5 } & More than 10 years & 77 & 4.35 & 0.36 \\
\cline { 2 - 5 } & Total & 256 & 4.26 & 0.35 \\
\hline
\end{tabular}

It is noted from Table (12) that there are apparent differences between the arithmetic averages for the degree of practicing self-evaluation based on the standards of the Arab Organization for Quality Assurance of Education for Private School Leaders, according to the gender variable, as the owners of (female) category obtained the highest arithmetic mean of (4.31), while The owners of the category (male) obtained arithmetic mean value of (4.18), and with regard to the variable of years of experience, the owners of the category (more than 10 years) obtained the highest arithmetic mean of (4.35), followed by owners of a category (from 5-10 years) with an average It reached (4.23), while the owners of the category (less than 5 years) got an average score of (4.21), and to determine whether the differences between the averages are The machine at the degree of statistical significance $(0.05=\alpha)$ was applied analysis of variance with the design duo World $2 * 3$ (Two way ANOVA), The results of the analysis of variance as shown in the table (13):

Table (13)

Binary variance analysis to find the significance of the differences in the degree of practicing self-evaluation based on the standards of the Arab Organization to ensure the quality of education for private school leaders, according to the variables of study, gender, and experience

\begin{tabular}{|l|l|l|l|l|l||}
\hline \hline Source of contrast & Sum of squares & Degree of freedom & Mean squares & F value & Sig. \\
\hline gender & 0.644 & 1 & 0.644 & 5.404 & $\mathbf{0 . 0 2 1}$ \\
\hline Experience & 0.507 & 2 & 0.253 & 2.128 & $\mathbf{0 . 1 2 1}$ \\
\hline The error & 30.015 & 252 & 0.119 & & \\
\hline Total & 31.542 & 255 & & \\
\hline
\end{tabular}

* The difference is statistically significant.

The results in Table (13) indicate that there is a statistically significant difference at the level of $(\alpha=0.05)$ in the degree of self-evaluation practice based on the criteria of the Arab Organization for Quality Assurance of Education for Private School Leaders, according to the gender variable, based on the calculated value of $\mathrm{P}$ as it reached (5.404), And the level of significance (0.021), and the difference in favor of females was evidenced by an increase in the mean of the arithmetic that reached (4.31), compared to the mean for the male which was (4.18), and the researchers attribute the result in favor of females in the gender variable because females are more able to work with details of the quality of education and on Carry the workload because of the depth in detail. The results in the table indicate that there are no statistically significant differences at the level of $(\alpha=0.05)$ in the degree of self-evaluation practice based on the standards of the Arab Organization for Quality Assurance of Education for Private Schools Leaders, according to the variable of experience, based on the calculated value of (2.128), And the level of significance $(0.121)$. The researchers attribute this to the fact that the primary element in the appointment of leaders of private schools is in accordance with high skills, capabilities and quality education requirements, regardless of years of experience.

\section{Recommendations}

In the light of the study's results, the researchers recommend:

1)- Providing the principals in private schools with training courses about the way of forming groups for carrying out self-assessment. Such training courses must promote knowledge about the way of carrying out selfassessment in accordance with the standards of the Arab Organization for Quality Assurance of Education.

2)-Developing administrative and educational procedures in order to be carried out by leaders in private schools when carrying out self-assessment. These procedures must be consistent with the standards of the Arab Organization for Quality Assurance of Education.

\section{References}

Abdin, M., (2004), Economics of education, Cairo, the Egyptian Lebanese House.

Abu-Sharp, S., (2017), An educational suggested guide to activate the practices of managers in evaluating 
the performance of teachers in Jordanian secondary schools in light of international standards for evaluation. Published PhD thesis, University of Jordan, Amman, Jordan.

Accreditation Commission for Higher Education Institutions, (2010). Directory of Higher Education Institutions to conduct a self-assessment study, Amman, Jordan.

Al-Ajami, M. H., (2008), Accreditation and Total Quality Assurance for Secondary Education Schools, Alexandria: New University House.

Al-Alaq, B., (2010), Administrative leadership. Amman: Al-Yazouri Scientific for Publishing and Distribution.

Al-Dajani, (2011), The role of the self-evaluation process in spreading the culture of quality in the universities of the Gaza Strip from the perspective of the evaluation team. The Islamic University, Gaza, Palestine.

Al-Najjar, F., (2007), Total Quality Management, Productivity, and Technological Planning for Excellence, Increase, and Excellence, Alexandria: University House for Publishing.

Al-Saud, R., (2013), Educational leadership concepts and perspectives. 1st floor, Amman: Al-Safa House for Publishing and Distribution.

Aruka (2014). Self-Evaluation Standards Manual, Arab Organization for Education Quality, Amman, Jordan.

Ayash, D., (2015), The degree to which UNRWA directors in Gaza governorates practice self-evaluation and its relationship to strategic planning in the school. Published Master Thesis, Gaza: The Islamic University.

Berer, I., (2010), Quality of Education and the Millennium Development Goals Al Ain. UAE: University Book House.

Cornin, Melvyn Charies, (2004). Continuous Improvement in A New York State School District: A Case Study.Dissertation Abstracts International, A 65/04.p.1189, Oct.

Daradakh, A., (2004), The degree of applying total quality management in Al-Balqa Applied University from the viewpoint of educational leaders, Published $\mathrm{PhD}$ thesis, University of Jordan: Amman, Jordan.

Hernandez, Justo Rolando, Jr. (2002). Total Quality Management in Education: The Application of TQM in a Texas School District.Dissertation Abstracts International, A 62/11.p.3639, May.

Knowledge and Human Development Authority, (2017), School Monitoring and Evaluation Standards Framework, Ministry of Education, Abu Dhabi Education Council: Abu Dhabi.

Majeed, S. Z., and Muhammad, (2007), Total quality management: applications in industry and education. I (1), Amman: Safaa House for Publishing and Distribution.

Shahat, M., (2003), Total Quality and Academic Accreditation in Education, Riyadh: Al-Khuraiji for Publishing and Distribution.

Zaghoul, M., (2012), The degree to which academic departments in Jordanian universities possess the skills of self-evaluation study. Published Master Thesis, Jerash University, Amman, Jordan.

AL-Qudah, M. and Fallouh, R. (2020). The Capability to Predict the Behaviors of the Students Enrolled in Jordanian Universities Through Their Aesthetic Values. The Journal of Education and Practice.11(4).DOI: 10.7176/JEP/11-4-11

Al-Qudah, M (2006). The Relationship between Family Socialization Patterns and Some Personality Attributes of Female Undergraduates at Mu'tah University, Jordan Journal of Educational Sciences, 2(3): 155-168.

Al-Qudah, M (2017). The Extent University of Jordan Students Represent Islamic Values from Their Perspective, Dirasat: Educational Sciences, 44(4), 9: 257-275.

Yan, Z. (2016). The self-assessment practices of Hong Kong secondary students: Fingdings with a new instrument. Journal of Applied Measurement. 17(3). 335-353

Acknowledgement:

The researchers would like to thank the respondents who participated in the present study. 